\title{
Normality of The Mice's Fetal Spine during Fennel Flower Extract (Nigella sativa) Feeding
}

\author{
Nur Anita Suciyati ${ }^{\star}$, Nuning Nurcahyani, Sutyarso, Emantis Rosa \\ Jurusan Biologi Fakultas Matematika dan Ilmu Pengetahuan Alam Universitas Lampung \\ JI. Prof. Soemantri Brodjonegoro, No 1, Bandar Lampung 35145 \\ `Email: anitasuciyati@gmail.com
}

\begin{abstract}
Black cumin (Nigella sativa) is an annual flowering herbal plant that is widely planted in India, Egypt, and the Middle East. Black cumin essential oil contains p-cymene, a-pinene, dithymoquine, thymohydroquinone, and thymoquinone (more than $50 \%$ ). This study aims to determine the effect of black cumin extract on the structure of the spine, length, and fetal weight of the mouse. The study was conducted in December 2019 to February 2020 at the Zoology and Botany Laboratory of the Faculty of Mathematics and Natural Sciences, Universitas Lampung. This study uses a Completely Randomized Design (CRD) consisting of 4 groups, each group with 5 repetitions (K1, P1, P2, P3). Black cumin extract is given orally as much as $0.3 \mathrm{ml} /$ day on the 6th to 17 th day of pregnancy. The control group K1 (Aquabides), P1 was given black cumin extract $(2.1 \mathrm{mg} / 30 \mathrm{~g}), \mathrm{P} 2(8.4 \mathrm{mg} / 30 \mathrm{~g})$, and P3 $(33.6 \mathrm{mg} / 30 \mathrm{~g})$. Data on the structure of the spine were observed descriptively while the length and weight of the fetus of mice were analyzed using ANOVA (Analysis of Variance) with a significance level of $\alpha=5 \%$. The results obtained on the structure of the spine from each treatment did not cause abnormalities in the structure of the mice's fetal spine. Black cumin contains calcium, magnesium, potassium, sodium, and iron which are useful in the process of bone growth and development. Besides, the results of fetal length and weight data based on the ANOVA test one factor level $\alpha=5 \%$ statistically did not show a decrease in the length and weight of the fetus of mice.
\end{abstract}

Keywords: Mice (Mus musculus L.), black cumin (Nigella sativa), spinal anatomical structure, fetal length, fetal weight.

\section{PENDAHULUAN}

Saat ini, tanaman obat masih menjadi sebagai salah satu alternatif dalam pengobatan masyarakat Indonesia. Obat tradisional sangat diminati dan berkembang dengan baik sebagai alternatif yang lebih aman, memberikan efek samping yang lebih rendah dan memberikan hasil yang optimal apabila dikonsumsi dengan tujuan pengobatan (Agusta, 2001).

Jintan hitam atau Nigella sativa merupakan salah satu tanaman yang tumbuh subur di wilayah tropis. Nama lain jintan hitam adalah Habbatussauda yang berasal dari bahasa arab, dari kata habbah yang berarti biji atau sauda yang berarti hitam, jika diterjemahkan dalam bahasa Indonesia menjadi biji jintan hitam dan dalam bahasa inggris Blackseed atau Blackcumin. Tanaman ini termasuk famili Ranunculaceae, yang merupakan tanaman berbiji. Jintan hitam juga tergolong tanaman gulma yang tumbuh semusim dengan tinggi $20-50 \mathrm{~cm}$. Penyebaran tanaman ini meliputi wilayah Mediterania Timur hingga ke wilayah India dan Asia Tenggara termasuk Indonesia. Jintan hitam telah lama dimanfaatkan sebagai tanaman obat khususnya pada bagian biji. Selain telah lama digunakan sebagai obat tradisional, tanaman ini juga banyak digunakan sebagai bumbu masakan di daerah Timur Tengah (Gilani dan Anwarul Hasan, 2004).

Penelitian Attaurrahman menyebutkan bahwa pada biji jintan hitam telah diketahui mengandung beberapa senyawa alkaloid seperti Nigelidin. Selain 
itu dari penelitian sebelumnya juga telah diketahui pada biji jintan hitam terkandung beberapa alkaloid lain dari seperti nigelisimin, nigelisin, nigelisimin Oksida, minyak atsiri yang mengandung nigellon dan lainnya (Rastogi, dan Mehrotra. 1993).

Pada minyak atsiri jintan hitam diketahui mengandung dithymoquinone, thymohydroquinone, nigellone, carvacrol, d-limonene, dcitronellol, methoxypropyl benzenediol dan thymol yang memiliki aktivitas farmakologi, diantaranya sebagai penghilang sakit (analgesik), antipembengkakan (antiinflamasi), antialergi (antihistamin), mampu menghambat proliferasi (produksi) sel kanker, antiangiogenesis (menghentikan pembentukan pembuluh darah bagi sel kanker), antioksidan dan antidiabetes mellitus dll (Junaedi et al., 2011).

Berbagai bahan kimia yang terkandung dalam jintan hitam (Nigella sativa) salah satunya yaitu senyawa thymoquinone yang diketahui dapat menyebabkan relaksasi otot polos pada uterus sehingga dapat mengakibatkan peningkatan pendarahan haid dan dapat menyebabkan abortus spontan pada kehamilan (Wijayanti et al., 2011).

Dalam upaya pemanfaatan tanaman sebagai bahan obat maka perlu dilakukan uji keamanan nya termasuk juga untuk ekstrak jintan hitam. Uji keamanan merupakan suatu uji dengan memberikan faktor atau zat tertentu untuk melihat ada tidaknya kelainan pada fetus hewan uji akibat pemberian zat tersebut. Pada penelitian ini digunakan ekstrak jintan hitam yang diberikan kepada mencit yang sedang hamil selama periode organogenesis yaitu pada kehamilan hari ke-6 sampai ke-17. Uji teratogenik tersebut diharapkan dapat menjadi dasar bagi penggunaan jintan hitam sebagai bahan baku obat-obatan agar dapat dipekatkan menggunakan alat rotary evaporator selama 4 jam dengan suhu $50^{\circ} \mathrm{C}$ dan tekanan $120 \mathrm{~atm}$, setelah itu di oven dengan suhu $40^{\circ} \mathrm{C}$ hingga diaplikasikan pada manusia sehingga tidak menimbulkan akibat yang berbahaya (Almahdy, 2011).

\section{BAHAN DAN METODE}

\section{Alat dan Bahan}

Alat yang digunakan dalam penelitian ini meliputi : Mikropipet, mikroskop steril, timbangan analitik, seperangkat alat bedah, sonde lambung, rotary evaporator, jarum suntik, kertas label dsb.dilaksanakan pada bulan Desember 2019 - Februari 2020 di Laboratorium Zoologi dan Botani Jurusan Biologi FMIPA Universitas Lampung

Bahan yang digunakan: 20 ekor mencit dengan berat sekitar 30 gram yang didapatkan dari Balai Veteriner Lampung, etanol 96\%, ekstrak jintan hitam, aquabides, pur ayam, gliserin, larutan Alizarin Red, kloroform, dan larutan $\mathrm{KOH}$ $01 \%$.

\section{Cara Kerja}

Persiapan kandang dan hewan uji

Kandang mencit beserta penutupnya yang digunakan yaitu berukuran $50 \times 50 \mathrm{~cm}$ dari bahan kawat berukuran $15 \times 15 \mathrm{~mm}$ sebanyak 20 unit, dibersilkan dengan alkohol dan diberi alas berupa sekam padi. Mencit dalam kondisi fertil kemudian diaklimatisasi selama 1 minggu dengan diberi pakan berupa pur ayam dan air minum setiap harinya.

\footnotetext{
Persiapan dan Pembuatan Ekstrak Jintan Hitam

Pembuatan ekstrak jintan hitam dengan metode maserasi. Biji jintan hitam dibersihkan, dicuci, dan dijemur hingga kering kemudian dihancurkan hingga menjadi serbuk. Dilakukan maserasi dengan cara merendam 500 gram serbuk biji jintan hitam dalam \pm 2 liter larutan etanol dengan 3 tahapan yaitu selama $3 \times 24$ jam, 1x 24 jam, dan 1x24 jam. Kemudian disaring menggunakan kertas saring, cairan hasil saringan tersebut lalu didapatkan ekstrak jintan hitam yang kental.
} 
Pemberian Perlakuan

Satu ekor mencit betina disatukan dengan satu ekor mencit jantan ke dalam satu kandang lalu diberi pakan dan air minum. Pemberian ekstrak jintan hitam pada induk mencit dilakukan dengan cara dicekok (secara oral) menggunakan alat sonde lambung mulai dari kehamilan hari ke 6 sampai ke 17 (Silvia, 2011).

Pemberian ekstrak jintan hitam diberikan secara oral sebanyak $0,3 \mathrm{ml} /$ hari pada induk mencit, dengan dosis :

1. Kontrol, diperlakukan dengan diberi aquabides (K1)

2. Dosis perlakuan $1=2,1 \mathrm{mg} / 30 \mathrm{gBB}$

3. Dosis perlakuan $1=8,4 \mathrm{mg} / 30 \mathrm{gBB}$

4. Dosis perlakuan $1=33,6 \mathrm{mg} / 30 \mathrm{gBB}$

\section{Pengamatan}

Pembedahan terhadap mencit betina dilakukan dengan menggunakan seperangkat alat bedah setelah kehamilan hari ke-18. Seluruh mencit baik dari kelompok kontrol maupun perlakuan dibius menggunakan kloroform. Mencit dibedah lalu fetus dikeluarkan dari uterus, Selanjutnya dibersihkan dengan air mengalir. Setelah itu, dilakukan penimbangan berat fetus dan pengukuran panjang fetus. Selanjutnya dilakukan preparasi tulang belakang fetus dengan pewarna Alizarin Red dengan cara menambahkan $6 \mathrm{mg}$ bubuk Alizarin Red ke dalam 1 liter larutan $\mathrm{KOH}$ 1\% (Manson dkk, 1982). Pengamatan struktur tulang belakang diamati secara deskriptif untuk melihat ada atau tidaknya kelainan dibandingkan dengan fetus kontrol.

\section{Analisis data}

Data hasil penelitian berupa anatomi struktur tulang belakang fetus dianalisis secara deskriptif. Sedangkan, panjang dan berat fetus dianalisis menggunakan ANOVA (Analysis of Variance). Apabila terdapat perbedaan yang nyata maka akan dilanjutkan dengan uji beda nyata terkecil (BNT) pada taraf $5 \%$.

\section{HASIL DAN PEMBAHASAN}

\section{Hasil}

Panjang dan Berat Fetus Mencit

Pada kehamilan hari ke 18, induk mencit dibedah dan fetus di keluarkan dari uterus. Data panjang badan fetus mencit disajikan pada Gambar 1.

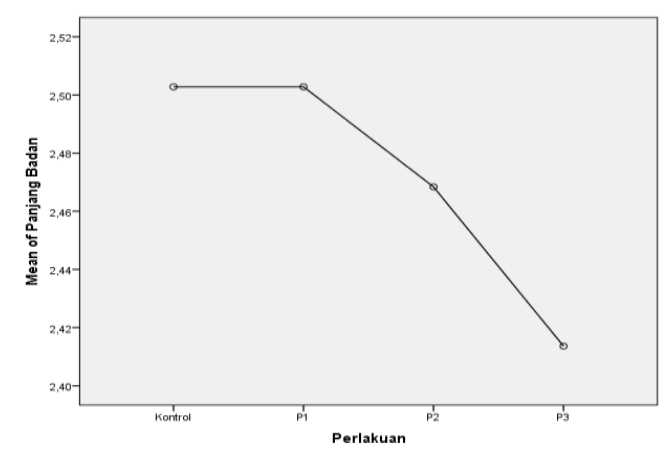

Gambar 1. Penurunan panjang badan fetus setelah pemberian ekstrak jintan hitam. Angka yang diikuti huruf superskip tidak menunjukkan beda nyata berdasarkan uji BNT 5\%

Berdasarkan Gambar 1, dapat diketahui bahwa pengaruh ekstrak jintan hitam (Nigella sativa) terhadap panjang badan fetus mencit secara statistik (One Way ANOVA $\alpha=5 \%$ ) tidak menunjukkan adanya perbedaan yang signifikan $(\alpha<0,05)$, sehingga tidak dilakukan uji lanjut BNT taraf $\alpha=5 \%$. Semua kelompok kontrol dengan kelompok dosis perlakuan 1 yaitu 2,1 mg/g BB, perlakuan 2 yaitu 8,4 $\mathrm{mg} / \mathrm{g} \mathrm{BB}$, dan perlakuan 3 yaitu 33,6 mg/g BB menunjukkan bahwa terjadi penurunan panjang badan fetus mencit. Penurunan panjang badan fetus mencit tertinggi terdapat pada dosis perlakuan 3 yaitu $33,6 \mathrm{mg} / \mathrm{g} \mathrm{BB}$.

Data Berat badan fetus mencit disajikan pada Gambar 2. 


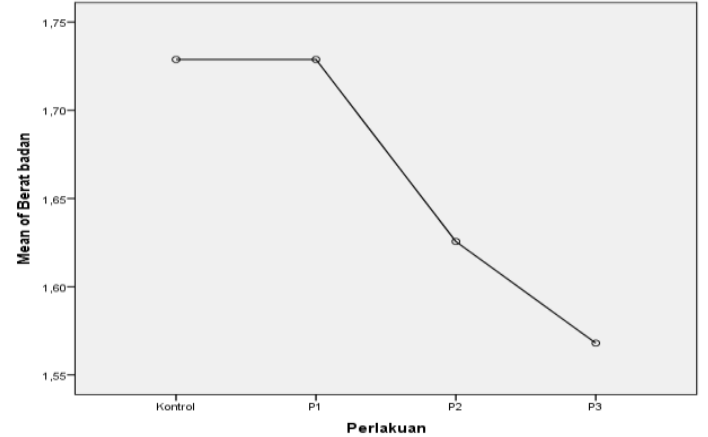

Gambar 2. Penurunan berat badan fetus setelah pemberian ekstrak jintan hitam. Angka yang diikuti huruf superskip tidak menunjukkan beda nyata berdasarkan uji BNT $5 \%$

Berdasarkan Gambar 2, setelah dilakukan uji statistik (One Way ANOVA $\alpha=5 \%$ ) dapat diketahui bahwa pengaruh ekstrak jintan hitam terhadap berat badan fetus mencit tidak menunjukkan perbedaan yang signifikan $(\alpha<0,05)$. Sehingga tidak diperlukan uji lanjut BNT taraf $\alpha=5 \%$. Semua kelompok kontrol dengan kelompok dosis perlakuan 1 yaitu $2,1 \mathrm{mg} / \mathrm{g} \mathrm{BB}$, perlakuan 2 yaitu $8,4 \mathrm{mg} / \mathrm{g}$ $\mathrm{BB}$, dan perlakuan 3 yaitu $33,6 \mathrm{mg} / \mathrm{g} \mathrm{BB}$ menunjukkan terjadinya penurunan berat badan fetus mencit. Penurunan berat badan fetus mencit tertinggi terdapat pada dosis perlakuan 3 yaitu 33,6 mg/g BB.

\section{Tulang Belakang Fetus}

Fetus mencit yang sudah dikeluarkan dari uterus dan dibersihkan organ dalamnya Selanjutnya dilakukan preparasi tulang belakang fetus dengan menggunakan larutan Alizarin Red.

Berdasarkan Gambar 3, pengamatan terhadap kelainan struktur tulang belakang fetus mencit dilakukan dengan cara mengamati struktur tulang belakang fetus yang meliputi servikalis, torakalis, dan lumbaris dengan menggunakan pewarnaan Alizarin Red. Pada penelitian ini tidak ditemukan adanya kelainan tulang belakang fetus kontrol dengan tulang belakang fetus yang diberi perlakuan.

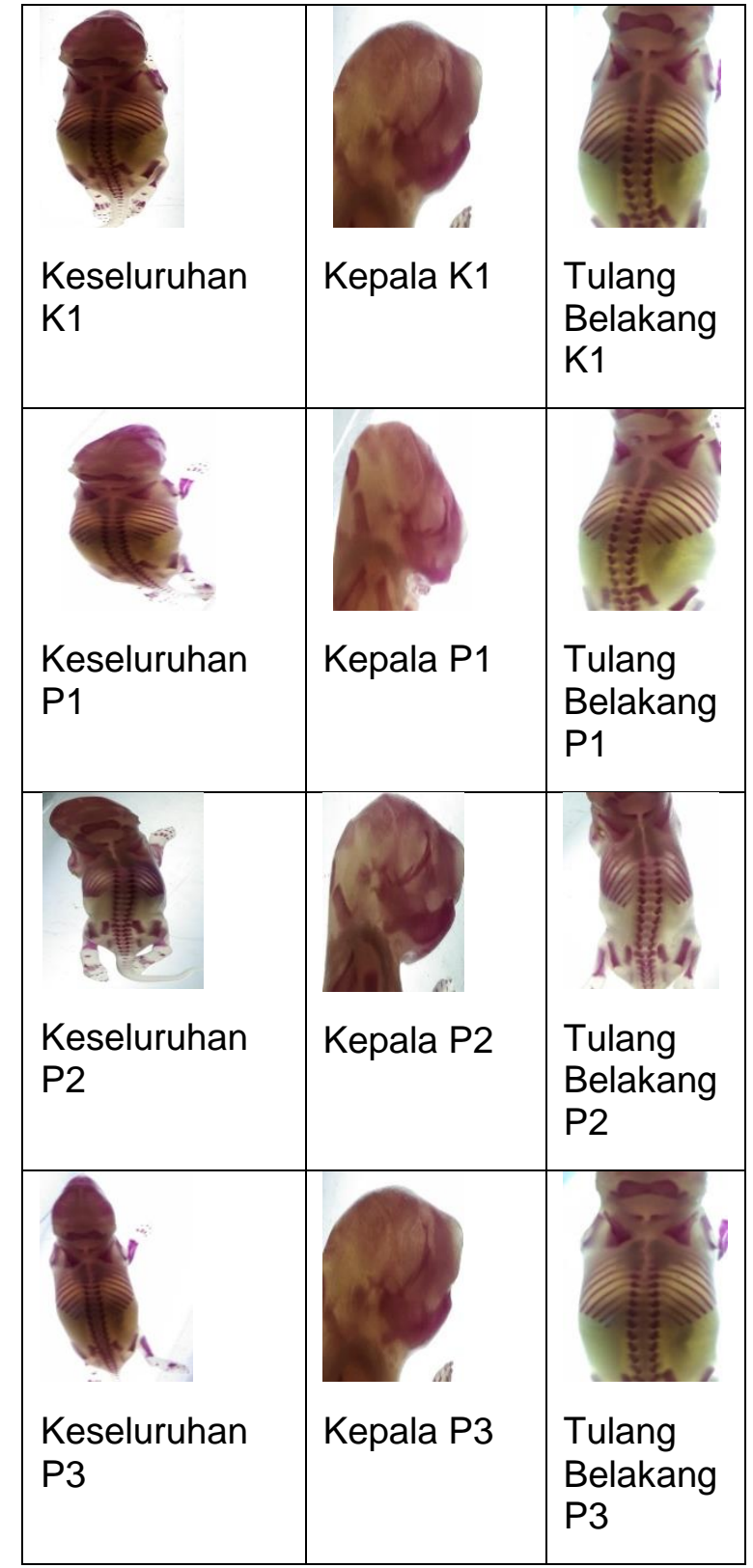

Gambar 3. Anatomi struktur tulang belakang fetus mencit (Mus musculus L.) setelah pemberian ekstrak jintan hitam (Nigella sativa) pada induknya. K1 : Kontrol; P1 : dosis 2,1 mg; P2 : dosis 8,4 $\mathrm{mg}$; P3 : dosis $33,6 \mathrm{mg}$ 


\section{Pembahasan}

Panjang dan Berat fetus mencit

Pengamatan panjang badan fetus merupakan parameter yang sensitif yang menandakan adanya hambatan pada pertumbuhan fetus mencit. Penurunan panjang badan fetus merupakan efek teringan dari ekspresi teratogen dari kandungan ekstrak jintan hitam (Nigella sativa) sehingga mampu menjadi indikator menghambat pertumbuhan akibat gangguan terhadap proses-preoses yang mendasari pertubuhan seperti metabolisme, sintesis didalam sel, dan pembelahan sel (Santoso, 2006). Pada penelitian ini panjang rata-rata fetus tidak memiliki perbedaan secara bermakna setelah dilakukan analisa statistik (One Way ANOVA $\alpha=5 \%$ ). Namun demikian, dari Gambar 1 dapat terlihat penurunan panjang badan fetus seiring dengan kenaikan dosis ekstrak jintan hitam.

Gangguan pertumbuhan yang terjadi diduga akibat induksi zat aktif yang terkandung dalam ekstrak jintan hitam, zat tersebut diduga dapat menghambat siklus sel, sebagai anti proliferasi, dan menginduksi apoptosis (Shoeib et al., 2003).

Hal ini dimungkinkan ekstrak jintan hitam masuk ke dalam tubuh fetus dan menghambat pembelahan sel. Aktivitas penghambatan ini terkait dengan zat aktif seperti minyak atsiri, alkaloid dan flavonoid yang terkandung dalam ekstrak jintan hitam. Namun jika dilihat pada penurunan panjang badan fluktuatif yang didapatkan secara statistik masih menunjukkan hasil yang tidak signifikan, hal tersebut dimungkinkan karena kandungan yang bersifat negatif dari ekstrak jintan hitam masih dapat ditoleransi oleh tubuh fetus baik karena adanya kandungan zat positif seperti mineral dan nutrisi maupun kemampuan fetus untuk melakukan recovery.

Rata-rata berat badan fetus mencit di setiap kelompok perlakuan mengalami penurunan di setiap perbedaan dosis, namun secara statistik tidak memiliki perbedaan yang nyata. Penurunan berat badan fetus adalah efek dari pemberian ekstrak jintan hitam pada fase organogenesis sehingga menyebabkan kelainan berupa berat badan yang tidak normal. Berat badan yang tidak normal terjadi karena senyawa teratogen pada ekstrak jintan hitam mempengaruhi poliferasi sel, sehingga terjadi hambatan pada sintesis asam nukleat, protein, atau polisakarida (Wilson, 1973 dan Siburuan dan Marlinza, 2009).

Berbagai senyawa yang terkandung dalam ekstrak jintan hitam membuat ekstrak jintan hitam memiliki efek sitotoksik. Pada saat fetus, sel-sel tubuh mampu membelah dengan cepat sehingga sangat rentan terhadap senyawa yang bersifat toksik, dengan adanya efek sitotoksik dari ekstrak jintan hitam ini dimungkinkan dapat menyebabkan berat badan fetus yang diberi perlakuan lebih rendah dibandingkan dengan kontrol. $\mathrm{Hal}$ itu dapat terjadi karena ekstrak yang diberikan kepada induk mencit akan berpindah ke fetus melalui palasenta, yaitu melalui jalan yang sama yang dilalui oleh zat gizi yang diperlukan untuk pertumbuhan dan perkembangan fetus (Suryawati, 1990 dan Muna et al., 2011).

\section{Tulang Belakang Fetus}

Pengamatan anatomi struktur tulang belakang dapat diamati secara visual atau deskriptif. Hasil pengamatan penelitian ini menunjukkan dari induk mencit tidak adanya kelainan ataupun tidak adanya pengaruh pada semua janin yang diamati. Hal ini dapat diketahui dengan membandingkan tulang belakang fetus semua kelompok, baik antara fetus kontrol (normal) dengan fetus dari induk yang telah diberikan perlakuan ekstrak jintan hitam (Nigella sativa).

Pengamatan terhadap tulang belakang fetus secara visual dengan membandingkan tulang belakang fetus kontrol dengan fetus yang diberi perlakuan. Pada fetus normal terdapat 7 tulang servik, 13 tulang thorak, 6 tulang 
lumbalis, 6 tulang sakral, dan 2-3 tulang kaudal (Sukandar et al., 2008). Kemudian hasil pengamatan tersebut dibandingkan dengan tulang pada fetus yang telah diberi ekstrak jintan hitam (Nigella sativa) dengan dosis $2,1 \mathrm{mg} / \mathrm{g} \mathrm{BB}$, dosis $8,4 \mathrm{mg} / \mathrm{g}$ $\mathrm{BB}$, dan dosis $33,6 \mathrm{mg} / \mathrm{g}$ BB. Dari hasil perbandingan tersebut tidak ditemukan adanya perbedaan antara fetus kontrol dengan fetus perlakuan baik jumlah ruas tulang belakang maupun strukturnya.

Tidak terjadinya kelainan struktur tulang belakang pada ketiga kelompok dosis perlakuan fetus tersebut diduga disebabkan oleh fetus yang sedang tumbuh mengambil prioritas dari banyaknya jenis nutrisi dalan cairan induk sehingga tulang fetus dapat terus mengalami pertumbuhan dan berkembang. Hal ini berhubungan dengan fungsi plasenta sebagai tempat penyimpanan nutrisis bagi fetus. Plasenta menyimpan banyak nutrisi seperti kalsium, besi, protein, dan glukosa yang digunakan untuk pertumbuhan fetus. Selain plasenta, sebagian kalsium juga disimpan dalam tubuh seperti pada gigi dan tuang. Apabila kebutuhan kalsium fetus berkurang maka simpanan kalsium pada tulang dan gigi inilah yang akan dimobilisasi untuk osifikasi tulang pada fetus (Guyton, 1990).

\section{KESIMPULAN}

Berdasarkan hasil penelitian dapat disimpulkan bahwa pengaruh pemberian ekstrak jintan hitam (Nigella sativa) terhadap mencit hamil tidak menghambat pertumbuhan struktur tulang Belakang, panjang dan berat badan fetus mencit

\section{SARAN}

Perlu dilakukan penelitian lebih lanjut terhadap efek teratogenik ekstrak jintan hitam dengan penambahan dosis untuk melihat hubungan antara dosis dengan efek. Selain itu perlu dilakukan pengamatan lebih lanjut pada organ dalam fetus mencit.

\section{DAFTAR PUSTAKA}

Agusta, A. (2001). Awas Bahaya Tumbuhan Obat. (Internet). Terdapat pada: http://www.Indomedia.com/ Diakses pada: 23 september 2019

Almahdy, A. (2011). Uji aktivitas vitamin A terhadap efek teratogen warfarin pada fetus mencit putih. Medan : USU Press

Attaurrahman. (1995). Nigellidine A New Indazole Alkaloid From The Seed of Nigella sativa. Tetrahedrom Left:36(12): 1993-1994

Gilani, dan A. Hasan. (2004). A review of medicinal uses and pharmacological activities of Nigella sativa. Department of Biological and Biochemical Sciences The Aga Khan University Medical College, Karachi, Pakistan. Pakistan Journal of Biological sciences 7 (4). Hal: 441-451. Pakistan

Guyton, A.C. (1990). Fisiologi Kedokteran. Terjemahan Dharma, A., dan P., Lukmanto. EGC. Jakarta.

Junaedi E, S. Yulianti, S. Suty, ES. Kuncari. (2011). Kedahsyatan Habbatussauda. Agro Media Pustaka. Jakarta.

Manson, J.M., H. Zenick, dan R.D. Costlow. (1982). Teratology Test Method for Laboratory Animals. Ravent Press. New York.

Muna, L., Astirin, O.P., dan Sugiyarto. (2011). Uji Teratogenik Ekstrak Panduanusconoideus Varietas Buah Kuning Terhadap Perkembangan Embrio Tikus Putih (Rattus norvegicus). Nusantara Bioscience. 2. Pp 126-134.

Rastogi, R.P., dan Mehrotra, BN. (1993). Compendium Of Indian Medical Plants New Delhi: CSIR.

Santoso, H.B. (2006). Pengaruh Kafein Terhadap Penampilan Reproduksi 
dan Perkembangan Skeleton Fetus Mencit (Mus musculus L.). Jurnal Biologi X:39-48

Setyawati, I. (2009). Morfologi Fetus Mencit (Mus musculus L.) Setelah Pemberian Ekstrak Daun Sambiloto (Andrographis paniculata Nees). Jurnal Biologi. 13 (2). pp 41-44.

Shoeib, M., N. Sidhpura, S. Shafait. (2003). Investigating The Actions Of Bupropion On Dependence Related Effects Of Nicotine In Rats. Psychopharm;165:405-12.

Siburuan, J., dan R. Marlinza. (2009). Efek Pemberian Ekstrak Akar Pasak Bumi (Eurcyoma Longifolia Jack) pada Tahap Prakopulasi Terhadap Fertilitas Mencit (Mus musculus L.) Betina. Biospecies, 2:24-30.

Silvia, G.A. (2011). Pengaruh Pemberian Suspensi Akar Manis Terhadap Perkecambahan Janin pada Mencit Bunting. Skripsi. FMIPA. Universitas Indonesia. Jakarta. pp 14-15.

Sukandar, E.Y., I. Fidrianny, dan , A.N. Garmana. (2008). Pengaruh Kombinasi Ekstrak Umbi Lapis Bawang Putih Dan Ekstrak Rimpang Kunyit Tehadap Janin Mencit. JKM. 8(1). pp 36-44. SwissWebster.

Wilson dan Warkany. (1975). Teratology Principles and Techniques. University of Chicago Press. Chicago IL. 